\section{Prof. J. Schetelig}

JАКов SсHETELiG, professor of minoralogy and geology in the University of Oslo, died on October 17, 1935, after several years of ill-health.

Schetelig started his scientific career as assistant to Fridtjof Nansen in working out the oceanographical results of the first Fram expedition. Later, for a short period, he acted as assistant in the Physical Institute of the University of Oslo. In 1905, under the inspiring influence of Prof. W. C. Brögger, he transferred to the Mineralogical Institute; and in 1917 succeeded Brögger as professor and director of the Mineralogical and Geological Museum.

Prof. Schetelig published work on the moraines of the Oslo Fjord, but most of his researches were connected with petrology and tectonics. He produced many papers on the mineralogy of Norwegian pegmatites, especially from the extreme south of Norway (Setesdal), and described a new silicate of scandium, thorveitite. He also suggested the possibility that certain granites of north-western southern Norway, generally regarded as Archæan, might be of Caledonian age. His greatest achievements are connected with the Oslo region. When Schetelig took up geology, Brögger was just preparing a new set of geological maps, which would indicate the distribution of the main types of igneous rocks described in his classical monographs of the 'eighties. Schetelig entered into this task with great enthusiasm and energy. In the last two decades, a large number of geological maps on the scale of $1: 100,000$ have been published by Brögger and Schetelig in collaboration; and in 1923 a general map on the scale of $1: 250,000$ appeared. This latter was highly appreciated by the sixty members of the Geologists' Association who in 1934 spent ten days in the region.

While tracing the igneous outcrops, Schetelig was struck by the circular outline, not only of many plutonic bodies, but also of lava fields, which evidently had been subject to subsidence. He was the first in Norway to connect these features with the cauldron-subsidence theory, so clearly demonstrated by Scottish geologists in the classic areas of Glen Coe and Ben Nevis. In this way he initiated comparative studies between Norwegian and British magmatic phenomena, of general interest and full of promise for the future.

Prof. Schetelig was an outstanding figure in geology, who will be missed by friends and colleagues in many countries.

Olaf Holtedahl.

\section{H. B. Quennell}

ThE death of Mr. Charles Henry Bourne Quennell, which took place on December 5 at the age of sixtythree years, cannot be allowed to pass without reference in NATURE. By profession an architecthe served on the council of the Royal Institute of British Architects in 1912-15-he was the author in collaboration with his wife, formerly Miss Marjorie Courtney, the painter, of a series of books for children and young people, which have been widely adopted in schools, and by the excellence of their text and illustration have strongly stimulated interest in the cultural background of the more formal study of history. In this field, the authors were not indeed the pioneers, but by their thorough and scholarly methods, their detailed acquaintance with tho archæological data, as well as their judgment in selection and presentation of the material both in text and illustration, they achieved a well-deserved success. Their best-known series deals with 'every-day things' in the old and new stone ages, the bronze and iron ages, Roman Britain, and the Anglo-Saxon, Viking and Norman periods.

\section{Radó de Kövesligethy}

A BRIEF account of the life and work of this wellknown seismologist by Prof. B. Simon appears in the last number of the Bollettino of the Italian Seismological Society $(33,200-205$ (1935)). He was born on September 1, 1862, at Verona, at that time under Austro-Hungarian dominion, both his parents being Hungarians. He spent the years 1881-84 at the University of Vienna and received the degree of doctor in the latter year. After this, he worked in succession in the Astronomical Observatory of Ogyalla, in the Central Office of Meteorology of Budapest, and as assistant to the celebrated geophysicist Baron L. Eötvös. In 1897, he was appointed professor of cosmography at Budapest. He was ono of the founders of the International Association of Seismology, of which he was elected general secretary in 1905. From this time onward, he devoted himself almost exclusively to seismology, his contributions to the science relating to the angle of emergence of seismic waves, the general theory of carthquakes, the depth of the focus, the prevision of earthquakes, etc. He died on October 11,1934 , after a long illness.

We regret to announce the death of Prof. Ettore Marchiafava, the eminent Italian malariologist. $\mathrm{He}$ was born on January 3, 1847, in Rome, where he qualified in 1872. After acting as assistant to Tommasi-Crudeli, he became professor of morbid anatomy at Rome in 1883, and succeeded Prof. G. Bacelli in 1916 in the chair of clinical medicine in the University of Rome, from which he retired in 1921. His works on the origin of melanæmia in malaria in conjunction with A. Celli (1887) and on restivo-autumnal fever with A. Bignami (1894) have boen translated into English in the New Sydonham Society's publications. $\mathrm{He}$ also wrote on diseases of the arteries, lungs and kidneys, and on the action of alcohol on the system.

WE regret to announce the following deaths :

Prof. Charles L. Jackson, emeritus professor of chemistry in Harvard University, known for his work in organic chemistry, on October 28 , aged eighty-eight years.

Dr. A. F. Shand, known for his works on psychology, especially "The Foundations of Character", on January 6, aged seventy-seven years. 